NOTICE: this is the author's version of a work that was accepted for publication in Economic Modelling. Changes resulting from the publishing process, such as peer review, editing, corrections, structural formatting, and other quality control mechanisms may not be reflected in this document. Changes may have been made to this work since it was submitted for publication. A definitive version was subsequently published in Economic Modelling, Vol. 38 (2014). DOI: 10.1016/j.econmod.2014.02.008 


\title{
URBANIZATION AND RENEWABLE AND NON-RENEWABLE ENERGY CONSUMPTION IN OECD COUNTRIES: AN EMIRICAL ANALYSIS
}

\author{
Ruhul A. Salim* \\ School of Economics \& Finance, \\ Curtin Business School, \\ Curtin University, Perth, WA 6845, \\ Australia \\ and \\ Sahar Shafiei \\ Department of Economics \\ Azad University, Science and Research Campus, \\ Ahvas, Iran \\ e-mail: shafiei.sahar@yahoo.com
}

*Corresponding author: Associate Professor Ruhul Salim, School of Economics \& Finance, Curtin Business School, Curtin University, Perth, WA 6102. Phone: +61 89266 4577, Fax: +61 89266 3026, E-mail: Ruhul.Salim@cbs.curtin.edu.au 


\title{
URBANIZATION AND RENEWABLE AND NON-RENEWABLE ENERGY CONSUMPTION IN OECD COUNTRIES: AN EMIRICAL ANALYSIS
}

\begin{abstract}
This article aims to analyse the impact of urbanization on renewable and non-renewable energy consumption in OECD countries by using the STIRPAT model and data for the period of 1980 to 2011. Demographic factors including total population, urbanization and population density are found to be significant factors, particularly with respect to non-renewable energy consumption. The results also reveal that while total population and urbanization positively influence non-renewable energy consumption, population density has a negative impact on non-renewable energy consumption. From the demographic factors only total population has a significant impact on renewable energy consumption. Granger causality results indicate that there is unidirectional causality from nonrenewable energy use to population density in the short run. However, no causal linkage is found between urbanization and non-renewable energy use. Likewise, no causal direction is seen between renewable energy use and any of the demographic factors.
\end{abstract}

Key Words: Renewable energy consumption; Non-renewable energy consumption; $\mathrm{CO}_{2}$ emissions; Urbanisation; STIRPAT model

JEL Classification: C23, C33, Q21, Q43, Q48 


\section{URBANIZATION AND RENEWABLE AND NON-RENEWABLE ENERGY CONSUMPTION IN OECD COUNTRIES: AN EMPIRICAL ANALYSIS}

\section{Introduction}

Urbanization leads to relative concentration of population as well as economic activities in urban areas. As a result of migration from rural to urban areas, in fact the labour force is transferred from the agricultural sector in the rural areas to the industrial and service sectors in the urban areas. This structural transformation of the economy causes many fundamental changes in natural resources and energy use as well. Although the transformation of production from the low-energy intensive agricultural sector to the high-energy intensive industrial sectors yet this sector is affected by the introduction of new technologies and industrialisation. Due to growing rates of urbanization the volume of production and the market range increase over the past decades. Moreover, urban living as compared to rural life is expected to require more energy as a result of travelling to work by fuel-using vehicles, and also constructing, operating, and maintaining urban infrastructure and services including housing, water supply, roads and bridges (Jones, 2004; Parikh and Shukla, 1995; Madlener and Sunak, 2011). Growing dependency on fossil fuels as a result of concentration of people in cities has led to efforts by policy makers to substitute clean energy resources for fossil fuels. For example, some major cities, particularly in developed countries, have begun to link homes and offices to renewable energy in order to create a fossil-fuel free district in the near future.

The urbanization-energy use relationship has been studied extensively in recent years, and while some researchers show that urbanization increases energy consumption, some others argue that urbanization can improve the efficient use of public infrastructure, resulting in less energy use. However, it is still less clear what sort of energy is more likely to be affected by urbanization. Recently, with the new approach to using more renewable energy, particularly for generating electricity in large cities, the question arises as to whether urbanization can expand the use of renewable energy. Therefore, it is important to study the impact of urbanization on disaggregated energy consumption in terms of renewable and non-renewable in order to gauge as to how urbanization affects disaggregated energy use and where policy makers should focus their attention in this regard. 
There are a number of studies that have investigated the urbanization-energy relationship, but none of these studies analyse the impact of urbanization on renewable and non-renewable energy consumption. This article aims to investigate the effects of urbanization on disaggregated energy consumption controlling for other demographic and economic factors such as population size, population density, economic growth, industrialization and tertiarisation etc. using data from the OECD countries over the period from 1980 to 2011.

The present study differs from the existing empirical studies in a number of ways. First, it estimates the impact of urbanization on non-renewable and renewable energy consumption employing a STIRPAT (STochastic Impacts by Regression on Population, Affluence, and Technology) model. Second, it controls for population density which is a key factor that influences energy consumption, and has been rarely considered in previous studies. Third, it takes into account statistical concerns over the presence of heterogeneity and cross-section dependence that can result in misleading inference and inconsistent estimates, and has been ignored by previous researchers.

The structure of the rest of the article proceeds as follows. Section 2 provides a critical review of empirical studies and develops research hypotheses. Section 3 describes the analytical models and data. The analysis of empirical results is presented in Section 4. Finally, Section 5 concludes the article and provides policy implications.

\section{Review of the Empirical Literature and Research Hypotheses}

\subsection{Review of the Empirical Literature}

While there has been useful modelling exercises on the relationship between energy consumption and economic growth, energy consumption and urbanization, but there is hardly any application between renewable and non-renewable energy consumption and urbanization. A good number of studies have been conducted over the last decades on the urbanization-energy consumption linkages either by using crosssection or by time series data or by pooling both time series and cross section data. ${ }^{1}$

\footnotetext{
${ }^{1}$ With the development of time series econometric modelling the number of studies on the causal linkages among economic variables such as energy consumption and income growth (e.g. Shahbaz et al 2012) energy consumption and urbanization (e.g. O'Neill et al 2012), financial development and energy consumption (e.g. Islam, et al 2013), financial development and economic growth (e.g. Hsues et al, 2013), stock prices and exchange rates (e.g. Liang et al 2013) are far too voluminous to review, we only focus on urbanization and energy consumption in this article.
} 
These studies have been conducted on divergent lines; some have focused on developing countries, some on developed and some on both developed and developing countries. In addition, some studies have focused on a single country and other on multiple countries. Using cross-section data for 59 developing countries in 1980, Jones (1991) concludes that a $10 \%$ increase in the proportion of the population living in cities increases per capita energy consumption by $4.5 \%$ to $4.8 \%$, holding constant per capita income and industrialization. However, Jones' findings may be subject to some limitations. For instance, the coefficients are estimated only based on a single year (1980) which might yield unreliable results due to using a very small sample size of data.

Parikh and Shukla (1995) also provide an early analysis of the relationship between urbanization and energy use over the period from 1965 to 1987 for a sample of developing countries. Their results, obtained from a panel data fixed-effects model, indicate that a $10 \%$ increase in a country's urban population leads to a $4.7 \%$ rise in its per capita total energy consumption. In a similar study, Imai (1997) employs a weighted least square method using data from 1980 to 1993 and finds a positive relationship between energy consumption and urbanization in Thailand, China, India, Iran, Japan, Turkey, USA and Germany. However, using a bivariate model in this study can increase the likelihood of reaching incorrect conclusions due to the omitted variables.

There are a number of studies dealing with the relationship between urbanization and aggregate energy consumption in China (Zhang and Zhao, 2001; Wei et al., 2003; Shen et al., 2005; Liu, 2009; O'Neill, 2012; Zhang and Lin, 2012), of which Liu (2009) finds the presence of a unidirectional causality running from urbanization to total energy consumption both in the long run and in the short run. Using a similar approach for a single country Turkey, Halicioglu (2007) finds a unidirectional causality running from urbanization and GDP to energy consumption. Mishra et al. (2009) also reveal a unidirectional causal relationship between urbanization and energy consumption in the short run for a panel of nine Pacific Island countries. In a very recent study in Tunisia, Shahbaz and Lean (2012) find bidirectional causality between industrialization and energy consumption in the long run and unidirectional causality from urbanization to energy consumption in the short run. 
York et al. (2003a) are the first to develop and use the STIRPAT model to study the impact of urbanization on aggregate energy use. Their results indicate that population is a major driver of the energy consumption; and urbanization, as an indicator of modernization, monotonically increases energy use. In contrast, Liddle (2004) finds that urbanization and population density negatively affect energy use in OECD countries from 1960 to 2000 . However, it is noteworthy to mention that Liddle considers road transport energy use in this study and implies that more densely populated and urbanized societies have less demand for personal transport. In a similar study on road transport energy use in high income countries Poumanyvong et al. (2012) obtain evidence opposite to that of Liddle (2004). Focusing on fourteen European Union Nations over the period from 1960 to 2000, York (2007) proves that demographic factors including population size, age structure and urbanization along with economic development affect energy consumption positively. However, predicting energy consumption for the year 2025, based on demographic and economic factors, the author shows that low fertility and thereby decline in population size in Europe can help restrict expansion in energy consumption.

It appears that Liddle and Lung (2010), after Liddle (2004) and York (2007), is the only recent study that investigates the effect of urbanization on energy consumption exclusively for a panel of developed countries. Employing a STIRPAT method for 17 developed countries covering the period from 1960 to 2005, the authors reveal that urbanization has a positive and fairly large effect on both residential energy consumption and residential electricity consumption. Considering different development stages in 99 countries from 1975 to 2005, Poumanyvong and Kaneko (2010) investigate the relationship between urbanization and energy use, controlling for population size, GDP per capita, share of industry and service sectors in GDP. These authors demonstrate that while urbanization increases energy use in the middleand high-income countries, it decreases energy use in the low-income countries.

Thus, a considerable number of studies have assessed the urbanization and energy consumption nexus. However, there is no consensus as yet as to how urbanization affects energy consumption. Furthermore, there are only a few studies on OECD countries on this issue. In addition, there are only a few studies that focus on population/urban density in the empirical literature although the population density in urban areas is closely related to urbanization and pollutant emissions. 
Newman and Kenworthy (1989) measure per capita transport energy consumption and population densities in a range of large cities in high-income countries and find that high population density decreases per capita transport energy use. However, Newman and Kenworthy's study is criticised for not using a multivariate analysis that can affect the research result. Their results are also said to be limited due to using 1980s data, which is suspected as not being accurate and consistent (Mindali et al., 2004).

Larivière and Lafrance (1999) find that in Canada, more urbanized areas have lower energy consumption per capita. Using data for 45 Chinese cities, Chen et al. (2008) reveal that urban density has a negative effect on household energy consumption. The authors argue that this effect is caused by compactness of residential structure. Thus, population density plays a critical role in energy use reduction and should be considered as a policy variable in empirical analysis. Given the limited number of studies on the relationship between population density and energy consumption further study gathering more empirical evidence on this issue is imperative.

\subsection{Research Hypotheses}

Some previous analysis identifies several causes of increased energy usage due to urbanization. First, the direct 'running costs' of cities are high for functions like space heating, air conditioning and lighting in buildings. Second, transporting goods and services now accounts for $30 \%$ of global energy consumption, a share that increases with the spatial and functional differentiation of economies and the shift from rural to urban lifestyles (Schurr et al., 1979). Third, cities are also centers of indirect energy consumption including most obviously those resources required to produce food and other biomass. With lower percentages of the population engaged in agricultural activities and the need to supply food to larger non-agricultural populations, primary sector activities become more resource and energy intensive (Jones, 1991). Finally, due to increases in travel distances and mobility of passengers and freight in urban areas more energy is likely to be consumed (Jones, 2004; Rodrigue et al., 2006; Hankey and Marshall, 2010; Poumanyvong et al., 2012). These reasons lead to the hypothesis that urbanization positively affects total energy use.

The lack of studies on urbanization and disaggregated energy consumption raises the question as to how urbanization influences renewable energy sources. Most of the 
world's energy comes from non-renewables and fossil fuels including oil, coal and gas. However, energy efficiency in the urban environment has become an important issue particularly for solving the problem of pollution in cities (Larivière and Lafrance, 1999). Some cities and regions have undertaken the provision and production of renewable energy, in addition to pursuing goals of increasing renewable energy consumption through land-use zoning, transportation, building and natural resource policies. Some cities in the OECD own and operate power generating facilities, which provide them with more options for increasing local use of renewable energies. Local governments also develop their own sources of renewable energy by capturing and converting energy from one or more renewable energy sources that exist in many cities and towns (IEA, 2009). Therefore, based on these evidences, it can be safely argued that if urbanization could increase renewable energy use, the consequence would be a substantial reduction in fossil fuels consumption which in turn results in less pollutant emissions.

There is also evidence indicating a negative association between the total energy consumption of a city and its overall density, that is, the higher the density, the lower energy consumption. For instance, Japan's urban areas are around five times denser than Canada's, and the use of energy per capita (as measured by total primary energy supply) in Japan is around $40 \%$ that of Canada's. The link is still visible for countries in the same geographical context with similar heating needs, such as Denmark and Finland; Denmark's urban areas are denser than Finland's by a factor of four and people in Denmark consume 2.5 times less energy than the Finns (Kamal-Chaoui and Robert, 2009). Thus, it can be hypothesized that increasing density is likely to reduce energy use.

\section{Methodology and Data Description}

\subsection{Empirical Model}

An analytical tool that is a useful framework for assessing the determinants of environmental degradation, is IPAT [Impact $=$ Population $\times$ Affluence $\times$ Technology] identity (Ehrlich and Holdren, 1971 and Holdren and Ehrlich, 1974). According to this identity, the main factors of environmental impacts (I) are Population (P), Affluence (A), and Technology (T). Affluence represents per capita consumption or production, and technology indicates the environmental impact per unit of consumption or production (York et al., 2003a; Lozano and Gutierrez, 2008). 
Following the IPAT identity, another approach the so-called ImPACT related to the case of GHG emissions, illustrates the key determinants of total emissions are population (P), per capita GDP(A), energy consumption per unit of GDP (C), and $\mathrm{CO}_{2}$ emissions per unit of energy consumption (T) (York et al., 2003a, Lozano and Gutierrez, 2008). Despite the fact that the IPAT and ImPACT are parsimonious and flexible, and also indicate easily the effect of driving forces on environmental conditions, they suffer from some limitations. For example, IPAT and ImPACT considers proportionality between the key determinant factors. Therefore, Dietz and Rosa (1997) presented a new model, namely STIRPAT.

STIRPAT basically has the following model:

$$
I_{i}=\alpha P_{i}^{b} A_{i}^{c} T_{i}^{d} e_{i}
$$

Taking the natural logarithm of both sides:

$$
\ln I_{i t}=\ln \alpha+b \ln \left(P_{i t}\right)+c \ln \left(A_{i t}\right)+d \ln \left(T_{i t}\right)+\ln e_{i t}
$$

where $\alpha$ represents a constant, $b, c$, and $d$ are the exponents of $P, A$, and $T$, which indicate respectively the elasticities of impact of population, affluence and technology. $e$ is the error term and $t$ denotes the year. The subscript $i$ illustrates the differences between the quantities of $I, P, A, T$, and $e$ across observational units.

According to York et al. (2003a), additional factors can be entered into the basic STIRPAT model as components of the technology $(T)$. However, the authors note that it is important to ensure that the additional factors are conceptually consistent with the multiplicative specification of the model. For instance, while Shi (2003) uses the share of industry and services in GDP as a proxy for $T$ in an investigation on emissions, Martínez-Zarzoso et al. (2007) employs the share of industry in GDP and energy intensity as a proxy. In a study of national energy use, York (2007) uses urbanization to express T. Similar to Shi (2003), Poumanyvong and Kaneko (2010) represent $T$ with the share of industry and service sectors in GDP in an analysis of energy use and emissions. In this study, following Shi (2003) and Poumanyvong and Kaneko (2010), $T$ is considered as the share of the industry and service sectors in GDP. As the main aim of this study is to estimate the impact of urbanization and population density on energy use, the basic model is modified by adding these two factors. While there are several studies that have added urbanization into the STIRPAT model (York et al. 2003a, 2003b; York 2007; Liddle and Lung 2010; Poumanyvong and Kaneko 2010; Poumanyvong et al. 2012), to the best knowledge of 
the authors, this is one of the first studies that includes population density in the model. Therefore, the empirical models for non-renewable and renewable energy consumption can be written as:

$$
\begin{aligned}
& \ln N_{i t}=\ln \alpha+b \ln \left(P_{i t}\right)+c \ln \left(A_{i t}\right)+d \ln \left(I N D_{i t}\right)+e \ln \left(S_{i t}\right)+f \ln \left(P D_{i t}\right)+ \\
& g \ln \left(U_{i t}\right)+\ln e_{i t} \\
& \ln R_{i t}=\ln \alpha+b \ln \left(P_{i t}\right)+c \ln \left(A_{i t}\right)+d \ln \left(I N D_{i t}\right)+e \ln \left(S_{i t}\right)+f \ln \left(P D_{i t}\right)+ \\
& g \ln \left(U_{i t}\right)+\ln e_{i t}
\end{aligned}
$$

In Equation 3, $N$ is non-renewable energy consumption, $P$ is total population size, $A$ is GDP per capita, IND is the share of the industry sector in GDP (industrialization), $S$ is the share of the service sector in GDP, $P D$ is population density and $U$ is urbanization. In Equation 4, $\mathrm{R}$ is renewable energy consumption and the variables on the right hand side remain the same as in Equation 3.

\subsection{Econometric Approach}

To provide valid empirical evidence on long run relationships among economic variables it is imperative to test the time series properties of the variables in question. Unit root test identifies whether the variables are stationary or non-stationary. There are a number of tests developed in the Time Series Econometrics for testing unit roots. We use several popular unit root tests such as augmented Dickey and Fuller (1979) (ADF) test, the Phillips and Perron (1988) (PP) test, Breitung (2000), Levin et al. (2002) (LLC) test, and Im et al. (2003) (IPS) test to check the stationarity of variables. We use several tests of unit roots in order to provide an analysis of sensitivity and robustness.

The next step is to use cointegration analysis. Cointegration analysis is intended to establish whether there exists a long-run relationship among the set of the integrated variables in question. There are several panel cointegration tests in the literature; each of them has its merits and drawbacks. However, panel cointegration tests of Westerlund (2006, 2007) and Fisher based on the multivariate framework of Johansen (1998) as proposed by Maddala and Wu (1999) are used for both non-renewable and renewable energy use models. Maddala and Wu's Fisher cointegration test is residual based and combine the $p$-values of individual (system-based) cointegration tests in order to obtain a panel test statistic while Westerlund tests are based on structural rather than residual dynamics and allow for a large degree of heterogeneity (e.g. individual specific short-run dynamics, intercepts, linear trends and slope parameters). 


\subsection{Panel Causality Test}

Panel cointegration tests are only able to indicate whether the variables are cointegrated and whether a long-run relationship exists between them. In order to examine the direction of causal linkages between the variables Granger causality is tested based on the following equations, considering each variable in turn as a dependent variable for each model (non-renewable and renewable energy use models):

$$
\begin{aligned}
& \Delta L N_{i t}=c_{0}+\sum_{j=1}^{m} \beta_{11 i j} \Delta L P_{i t-j}+\sum_{j=1}^{m} \beta_{12 i j} \Delta L A_{i t-j}+\sum_{j=1}^{m} \beta_{13 i j} \Delta L I N D_{i t-j}+ \\
& \sum_{j=1}^{m} \beta_{14 i j} \Delta L S_{i t-j}+\sum_{j=1}^{m} \beta_{15 i j} \Delta L U_{i t-j}+\sum_{j=1}^{m} \beta_{16 i j} \Delta L P D_{i t-j}+\lambda_{i t} e_{i t-1}+u_{1 i t} \\
& \Delta L R_{i t}=d_{0}+\sum_{j=1}^{m} \theta_{11 i j} \Delta L P_{i t-j}+\sum_{j=1}^{m} \theta_{12 i j} \Delta L A_{i t-j}+\sum_{j=1}^{m} \theta_{13 i j} \Delta L I N D_{i t-j}+ \\
& \sum_{j=1}^{m} \theta_{14 i j} \Delta L S_{i t-j}+\sum_{j=1}^{m} \theta_{15 i j} \Delta L U_{i t-j}+\sum_{j=1}^{m} \theta_{16 i j} \Delta L P D_{i t-j}+\gamma_{i t} e_{i t-1}+u_{1 i t}
\end{aligned}
$$

In Equation 5, $L N$ is non-renewable energy consumption and in Equation 6, $L R$ is renewable energy consumption. In both above equations, $L P$ is total population size, $A$ is GDP per capita, $L I N D$ is the share of the industry sector in GDP, $L S$ is the share of the service sector in GDP, $L P D$ is population density and $L U$ is urbanization.

The residuals obtained from estimating the long-run relationship between the variables in non-renewable and renewable energy use models are used as dynamic error correction terms in the above equations. The causal relationship between the variables is tested considering each variable in turn as a dependent variable in each equation. Because the first differences of the dependent variables are correlated with the first difference error terms in the above equations, it is necessary to use instrumental variable procedures to cope with this problem. A possible solution is represented by the Generalised Method of Moments (GMM) technique.

There are two widely used variants of GMM estimators in dynamic panel models, the GMM estimator in first difference, proposed by Arrelano and Bond (1991), and the GMM in system proposed by Blundell and Bond (1998). The first-differenced GMM approach consists in taking the equation to be estimated in first-differences in order to eliminate the specific-effect component. Then, lagged levels of the right hand side variables are used as instruments. In the system GMM estimator, lagged differences of the series are used as instruments for the equations. Blundell and Bond 
(1998) point out that the first-differenced GMM estimator has poor finite sample properties, and it is downwards biased, especially when $\mathrm{T}$ is small. Therefore, this study uses the system GMM estimator to estimate the Equations 5 and 6.

\subsection{Data Description}

The variables used in this study include total population, GDP per capita, industrialization, share of service sector in GDP, population density, urbanization, and renewable and non-renewable energy consumption. Total population is measured by midyear population size, and GDP per capita (US\$ in PPP, year 2000 prices) is gross domestic product divided by midyear population. While population living in urban areas (\% of total) is applied here as a reliable proxy for urbanization, industrial value added ( $\%$ of GDP) is considered as a proxy for industrialization. Services sector value added as the percentage of GDP is considered as a proxy for the share of the services sector in GDP. According to World Development Indicators, population density is defined as the number of people living per square Kilometre of land area. All these data are sourced from the World Bank's World Development Indicators. Renewable and non-renewable energy data are obtained from the U.S. Energy Information Administration (EIA). The 29 OECD countries are Australia, Austria, Belgium, Canada, Chile, Denmark, Finland, France, Germany, Greece, Hungary, Iceland, Ireland, Italy, Japan, South Korea, Luxembourg, Mexico, the Netherlands, New Zealand, Norway, Poland, Portugal, Spain, Sweden, Switzerland, Turkey, the United Kingdom and the United States. Due to unavailability of data, only 29 of the 34 countries that comprise the OECD are included in the analysis. The rationale behind selecting the time period from 1980 to 2011 is the unavailability of renewable energy data.

All the variables are converted into natural logarithms prior to conducting the analysis. To test for multicollinearity between independent variables, the variance inflation factors (VIF) for each predictor is calculated. The results (presented in Appendix Table 1) indicate no existence of severe multicollinearity between independent variables as all the VIF values are less than 10.

\section{Empirical Results}

\subsection{Panel Unit Root Test}

The empirical estimation begins with the examination of the stationarity properties of the variables by employing a number of popular panel unit root tests. These tests 
include augmented Dickey and Fuller (1979) (ADF) test, the Phillips and Perron (1988) (PP) test, Breitung (2000), Levin et al. (2002) (LLC) test, and Im et al. (2003) (IPS) are used test to check the stationarity of variables. The null hypothesis for each panel unit root test is that there is a unit root while the alternative hypothesis is no unit root. Table 1 displays the results of the panel unit root tests which suggest that all variables in question are non-stationary at their levels, but stationary at their first differences, i.e. each variable is integrated of order one.

Table 1: Panel Unit Root Tests without Structural Breaks

\begin{tabular}{|c|c|c|c|c|c|c|}
\hline Method & LP & LA & LIND & LS & $\mathrm{LU}$ & LPD \\
\hline \multicolumn{7}{|l|}{$\overline{A D F}$} \\
\hline Level & $\begin{array}{l}4.271 \\
(1.000)\end{array}$ & $\begin{array}{l}70.889 \\
(0.119)\end{array}$ & $\begin{array}{l}52.890 \\
(0.665)\end{array}$ & $\begin{array}{l}47.070 \\
(0.847)\end{array}$ & $\begin{array}{l}62.787 \\
(0.310)\end{array}$ & $\begin{array}{l}44.106 \\
(0.911)\end{array}$ \\
\hline $\begin{array}{l}\text { First } \\
\text { difference }\end{array}$ & $\begin{array}{l}-4.739 \\
(0.000) * * *\end{array}$ & $\begin{array}{l}164.514 \\
(0.000)^{* * *}\end{array}$ & $\begin{array}{l}288.792 \\
(0.000)^{* * *}\end{array}$ & $\begin{array}{l}221.686 \\
(0.000)^{* * *}\end{array}$ & $\begin{array}{l}80.649 \\
(0.026) * *\end{array}$ & $\begin{array}{l}136.584 \\
(0.000)^{* * *}\end{array}$ \\
\hline \multicolumn{7}{|l|}{$P P$} \\
\hline Level & $\begin{array}{l}16.738 \\
(1.000)\end{array}$ & $\begin{array}{l}33.266 \\
(0.996)\end{array}$ & $\begin{array}{l}31.542 \\
(0.998)\end{array}$ & $\begin{array}{l}38.933 \\
(0.074)^{*}\end{array}$ & $\begin{array}{l}0.318 \\
(1.000)\end{array}$ & $\begin{array}{r}31.097 \\
(0.998)\end{array}$ \\
\hline $\begin{array}{l}\text { First } \\
\text { difference }\end{array}$ & $\begin{array}{l}-2.542 \\
(0.005) * * *\end{array}$ & $\begin{array}{l}178.791 \\
(0.000)^{* * *}\end{array}$ & $\begin{array}{l}332.740 \\
(0.000)^{* * *}\end{array}$ & $\begin{array}{l}384.467 \\
(0.000) * * *\end{array}$ & $\begin{array}{l}97.195 \\
(0.001)^{* * *}\end{array}$ & $\begin{array}{l}78.324 \\
(0.038)^{* *}\end{array}$ \\
\hline \multicolumn{7}{|l|}{ Breitung } \\
\hline Level & $\begin{array}{l}5.636 \\
(1.000)\end{array}$ & $\begin{array}{l}4.629 \\
(1.000)\end{array}$ & $\begin{array}{l}0.395 \\
(0.653)\end{array}$ & $\begin{array}{l}1.608 \\
(0.946)\end{array}$ & $\begin{array}{l}5.079 \\
(1.000)\end{array}$ & $\begin{array}{l}0.274 \\
(0.608)\end{array}$ \\
\hline $\begin{array}{l}\text { First } \\
\text { difference }\end{array}$ & $\begin{array}{l}-1.150 \\
(0.024)^{* *}\end{array}$ & $\begin{array}{l}-2.740 \\
(0.003)^{* * *}\end{array}$ & $\begin{array}{l}-9.394 \\
(0.000)^{* * *}\end{array}$ & $\begin{array}{l}-8.232 \\
(0.000)^{* * *}\end{array}$ & $\begin{array}{l}-15.262 \\
(0.000)^{* * *}\end{array}$ & $\begin{array}{l}-1.586 \\
(0.056)^{*}\end{array}$ \\
\hline \multicolumn{7}{|l|}{$L L C$} \\
\hline Level & $\begin{array}{l}1.005 \\
(0.842)\end{array}$ & $\begin{array}{l}-0.997 \\
(0.159)\end{array}$ & $\begin{array}{l}-0.323 \\
(0.373)\end{array}$ & $\begin{array}{l}-0.325 \\
(0.372)\end{array}$ & $\begin{array}{l}3.377 \\
(0.999)\end{array}$ & $\begin{array}{l}3.661 \\
(0.999)\end{array}$ \\
\hline $\begin{array}{l}\text { First } \\
\text { difference }\end{array}$ & $\begin{array}{l}5.502 \\
(0.000) * * *\end{array}$ & $\begin{array}{l}-5.221 \\
(0.000)^{* * *}\end{array}$ & $\begin{array}{l}-15.189 \\
(0.000)^{* * *}\end{array}$ & $\begin{array}{l}-9.343 \\
(0.000)^{* * *}\end{array}$ & $\begin{array}{l}-3.774 \\
(0.000)^{* * *}\end{array}$ & $\begin{array}{l}-3.478 \\
(0.000) * * *\end{array}$ \\
\hline \multicolumn{7}{|l|}{ IPS } \\
\hline Level & $\begin{array}{l}4.355 \\
(1.000)\end{array}$ & $\begin{array}{l}-1.289 \\
(0.098) *\end{array}$ & $\begin{array}{l}1.910 \\
(0.971)\end{array}$ & $\begin{array}{l}1.142 \\
(0.873)\end{array}$ & $\begin{array}{l}0.374 \\
(0.646)\end{array}$ & $\begin{array}{l}6.971 \\
(1.000)\end{array}$ \\
\hline $\begin{array}{l}\text { First } \\
\text { difference }\end{array}$ & $\begin{array}{l}4.735 \\
(0.000)^{* * *}\end{array}$ & $\begin{array}{l}-7.629 \\
(0.000)^{* * *}\end{array}$ & $\begin{array}{l}-14.701 \\
(0.000)^{* * *}\end{array}$ & $\begin{array}{l}-10.833 \\
(0.000)^{* * *}\end{array}$ & $\begin{array}{l}-18.540 \\
(0.000)^{* * *}\end{array}$ & $\begin{array}{l}-5.408 \\
(0.000) * * *\end{array}$ \\
\hline
\end{tabular}

Note: Probabilities of the test statistics are presented in parentheses. $* * *, * *$ and $*$ indicate that the test statistic is significant at $1 \%, 5 \%$ and $10 \%$ levels, respectively. The Schwarz Information Criterion (SIC) has been used to determine the optimal lag length.

The above unit root tests do not control for structural breaks. These stationarity results may be unreliable if there is a presence of structural instability in series. To prevent achieving invalid results we employ the panel stationarity test of Carrion-i-Silvestre et al. (2005) allowing cross-sectional dependence, which assumes a highly flexible trend function by incorporating an unknown number of changes in 
level and slope. Table 2 presents the panel stationarity test allowing for structural breaks in series. These results indicate that the null hypothesis of stationarity is rejected for the total population, GDP per capita, industrialisation, share of the service sector in GDP and urbanization at 5\% level and for most of the variables at $2.5 \%$ and $1 \%$ by both the homogeneous and heterogeneous long-run versions of the test. The number of breaks and their position for each country and variable are also calculated by means of Monte Carlo simulations based on 20,000 replications. The results are provided in Appendix Table 2. The identified breaks in different series in all 29 countries are associated with various episodic events such as oil price shocks in the early 1980s, Asian financial crisis in 1998-99, slowdown of various big economies such as the US in 2001, US stock market collapse, terrorist attacks in New York, Afghanistan and Iraq wars in the 2000s and some big businesses collapsed in the mid2000s and so on. All these events contributed to the structural breaks in various series.

Table 2: Panel Unit Root Tests with Structural Breaks

\begin{tabular}{|c|c|c|c|c|c|}
\hline \multirow[t]{2}{*}{ Variables } & \multirow{2}{*}{$\begin{array}{l}\text { Bartlett } \\
\text { Kernel }\end{array}$} & \multirow{2}{*}{$\begin{array}{l}\text { Quadratic } \\
\text { Kernel }\end{array}$} & \multicolumn{3}{|c|}{ Bootstrap critical values } \\
\hline & & & $5 \%$ & $2.5 \%$ & $1 \%$ \\
\hline \multicolumn{6}{|l|}{$\overline{\mathrm{LP}}$} \\
\hline Homogeneous & $6.744 * * *$ & $6.514 * *$ & 6.323 & 6.510 & 6.711 \\
\hline Heterogeneous & $6.918 *$ & $7.131 *$ & 6.891 & 7.452 & 7.859 \\
\hline \multicolumn{6}{|l|}{ LA } \\
\hline Homogeneous & $11.428 * * *$ & $11.888 * * *$ & 9.781 & 9.979 & 10.163 \\
\hline Heterogeneous & $9.639 * * *$ & $9.519 * * *$ & 7.508 & 8.631 & 8.357 \\
\hline \multicolumn{6}{|l|}{ LU } \\
\hline Homogeneous & $10.249 * * *$ & $10.021 * *$ & 8.363 & 9.472 & 10.236 \\
\hline Heterogeneous & $9.381 * * *$ & $9.415^{* * *}$ & 7.501 & 8.993 & 9.303 \\
\hline \multicolumn{6}{|l|}{ LPD } \\
\hline Homogeneous & 5.326 & 5.461 & 5.513 & 5.815 & 6.012 \\
\hline Heterogeneous & $4.964 *$ & $5.433^{*}$ & 4.959 & 5.572 & 5.630 \\
\hline \multicolumn{6}{|l|}{ LIND } \\
\hline Homogeneous & $9.316 * * *$ & $9.322 * * *$ & 7.703 & 8.110 & 8.741 \\
\hline Heterogeneous & $8.120 * * *$ & $8.121 * * *$ & 5.504 & 6.823 & 7.330 \\
\hline \multicolumn{6}{|l|}{ LS } \\
\hline Homogeneous & $13.391 *$ & $13.731 * *$ & 12. 831 & 13.555 & 13.789 \\
\hline Heterogeneous & 12.097 & 12.280 & 13.561 & 13.829 & 13.995 \\
\hline
\end{tabular}

Note: The number of structural breaks is up to 5 . The long-run variance is estimated using both the Bartlett and the Quadratic spectral kernel with automatic spectral window bandwidth selection as in Sul et al. (2005). Furthermore, all bootstrap critical values allow for cross-sectional dependence. ***, ** and $*$ indicate that the test statistic is significant at $1 \%, 2.5 \%$, and $5 \%$ levels, respectively. 
It is apparent from Table 2 that all the variables are non-stationary at their levels even when allowing for structural breaks. However, the panel stationarity tests in first differences show that all variables are integrated of order one, consequently panel cointegration tests can be employed to study the long-run equilibrium process.

\subsection{Panel Cointegration Test}

Having identified that all the variables contain a panel unit root and are integrated of order one, the next step is to determine whether there is a cointegration relationship between the variables. Table 3 displays the results of the Johansen panel cointegration test. The results of the cointegration test from both a trace test as well as a maximum eigen-value test indicate the existence of cointegration at $1 \%$ significance level for both non-renewable and renewable energy use models.

Table 3: Johansen Fisher Cointegration Test for Non-renewable and Renewable Energy Use Models

\begin{tabular}{|c|c|c|}
\hline Model & $\begin{array}{l}\text { Fisher statistic } \\
\text { (from trace test) }\end{array}$ & $\begin{array}{l}\text { Fisher statistic } \\
\text { (from max-eigen test) }\end{array}$ \\
\hline \multicolumn{3}{|l|}{ Non-renewable energy-use model } \\
\hline None & $\begin{array}{l}1123.0 \\
(0.000)^{* * *}\end{array}$ & $\begin{array}{l}607.1 \\
(0.000) * * *\end{array}$ \\
\hline At most 1 & $\begin{array}{l}648.6 \\
(0.000)^{* * * *}\end{array}$ & $\begin{array}{l}323.7 \\
(0.000)^{* * *}\end{array}$ \\
\hline At most 2 & $\begin{array}{l}393.6 \\
(0.000) * * *\end{array}$ & $\begin{array}{l}210.7 \\
(0.000)^{* * *}\end{array}$ \\
\hline At most 3 & $\begin{array}{l}234.7 \\
(0.000)^{* * * *}\end{array}$ & $\begin{array}{l}152.5 \\
(0.000)^{* * *}\end{array}$ \\
\hline At most 4 & $\begin{array}{l}139.2 \\
(0.000)^{* * * *}\end{array}$ & $\begin{array}{l}120.0 \\
(0.000)^{* * *}\end{array}$ \\
\hline At most 5 & $\begin{array}{l}98.53 \\
(0.000)^{* * *}\end{array}$ & $\begin{array}{l}98.53 \\
(0.000)^{* * *}\end{array}$ \\
\hline \multicolumn{3}{|l|}{ Renewable energy-use model } \\
\hline None & $\begin{array}{l}1145.0 \\
(0.000)^{* * * *}\end{array}$ & $\begin{array}{l}587.2 \\
(0.000)^{* * *}\end{array}$ \\
\hline At most 1 & $\begin{array}{l}680.2 \\
(0.000) * * *\end{array}$ & $\begin{array}{l}351.4 \\
(0.000) * * *\end{array}$ \\
\hline At most 2 & $\begin{array}{l}397.4 \\
(0.000) * * *\end{array}$ & $\begin{array}{l}217.8 \\
(0.000)^{* * *}\end{array}$ \\
\hline At most 3 & $\begin{array}{l}227.6 \\
(0.000) * * *\end{array}$ & $\begin{array}{l}138.7 \\
(0.000)^{* * *}\end{array}$ \\
\hline At most 4 & $\begin{array}{l}145.2 \\
(0.000) * * *\end{array}$ & $\begin{array}{l}121.4 \\
(0.000)^{* * *}\end{array}$ \\
\hline At most 5 & $\begin{array}{l}106.7 \\
(0.000)^{* * *}\end{array}$ & $\begin{array}{l}106.7 \\
(0.000)^{* * *}\end{array}$ \\
\hline
\end{tabular}

Note: The Schwarz Information Criterion (SIC) has been used to determine the optimal lag length. *** indicates that the test statistic is significant at $1 \%$ level. 
Next, the Westerlund cointegration test controlling for cross-sectional dependence is conducted and the results are reported in Table 4. It is seen from this table that group-t and panel-a reject the null hypothesis of no cointegration at $1 \%$ and $5 \%$ significance levels respectively in both non-renewable and renewable energy use models. Therefore, overall evidence from the Johansen Fisher (Maddala and $\mathrm{Wu}, 1999$ ) and Westerlund (2006, 2007) tests for cointegration show that there is a long-run relationship between the dependent variables (non-renewable and renewable energy use) and the independent variables (total population, GDP per capita, share of the industry sector in GDP, share of service sector in GDP, urbanization and population density) in selected OECD countries. Given the presence of a panel cointegration relationship between the variables, the next step is estimation of the long-run structural coefficients.

Table 4: Westerlund Cointegration Test for Non-renewable and Renewable Energy Use Models

\begin{tabular}{lll}
\multicolumn{1}{c}{ Statistic } & Value & $P$-value \\
\hline Non-renewable energy-use model & & \\
\cline { 1 - 1 } Group-t & & \\
Group-a & -2.973 & $0.000^{* * * *}$ \\
Panel-t & -3.547 & 1.000 \\
Panel-a & -12.743 & $0.016^{* *}$ \\
& -3.858 & 0.998 \\
Renewable energy-use model & & \\
\hline Group-t & & $0.000^{* * *}$ \\
Group-a & -3.163 & 1.000 \\
Panel-t & -2.114 & $0.025^{* *}$ \\
Panel-a & -12.522 & 1.000 \\
\hline
\end{tabular}

Note: $* * *$ and $* *$ indicate that the test statistics are significant at $1 \%$ and $5 \%$ levels, respectively. Following Westerlund $(2006,2007)$ maximum lag length is selected according to $4(T / 100)^{2 / 9}$. The null hypothesis of the test is "no cointegration".

\subsection{Panel Long-Run Estimates}

Before moving to formal modelling, the diagnostic tests including cross-sectional dependence, heteroskedasticity and serial correlation are checked. The results of the diagnostic tests for non-renewable and renewable energy use models are presented in Appendix Table 3. The results of the different cross-section dependence tests under both random and fixed effects estimations show that the null hypothesis of no crosssectional dependence is rejected in both non-renewable and renewable energy use models under all of the used tests - Friedman, Frees, and Pesaran- meaning the residuals of the two models are correlated. The results of heteroskedasticity based on 
a modified Wald test indicate the existence of the problem of heteroskedasticity at a $1 \%$ level of significance in both models. Finally, the findings of serial correlation test based on Wooldridge suggest that the two models suffer from a positive serial correlation. In the case of the existence of cross-section error dependence, in addition to heteroskedasticity and serial correlation, conventional panel estimators (such as fixed or random effects) can result in misleading inference and even inconsistent estimators (Phillips and Sul, 2003). Pesaran (2006) proposes an estimation method, called Common Correlated Effects (CCE), which allows for unobserved factors to be correlated with exogenous regressors and idiosyncratic components to be independent across countries. Furthermore, this estimator holds under different situations such as serial correlation in errors, unit roots in the variables and possible contemporaneous dependence of the observed regressors with the unobserved factors (Kapetanios and Pesaran, 2007; Pesaran and Tosetti, 2011). Therefore, in this study, the common correlated effects (CCE) estimator by Pesaran (2006) is employed ${ }^{2}$.

The results of the long-run estimates of the variables are reported in Table 5. The estimated coefficients of total population are positive and statically significant at $10 \%$ level for non-renewable and renewable energy use. While the elasticity of nonrenewable energy use to population size is 1.763 , the elasticity of renewable energy use to population size is 0.710 . This result indicates that population growth increases energy consumption in terms of both non-renewables and renewables. However, the magnitude of the long-run elasticity of non-renewable energy use with respect to the population is much greater than the elasticity of renewable energy use with respect to the population. The positive relationship between population and energy use can be seen in some previous studies (York, 2007; Liddle and Lung, 2010; Poumanywong and Kaneko, 2010; Poumanywong et al., 2012).

GDP per capita has a positive and statistically significant effect on both nonrenewable and renewable energy use at $1 \%$ and 5\% levels, respectively. The results indicate that a $1 \%$ increase in GDP per capita increases non-renewable energy use by $0.537 \%$ and renewable energy use by $0.268 \%$ in the long run. The relationship between industrialization and both non-renewable and renewable energy use is positive and significant at $1 \%$ and $5 \%$ levels, respectively. The estimated coefficients

\footnotetext{
${ }^{2}$ For a detailed discussion of this approach refer to Pesaran (2006), and Pesaran and Tosetti (2011).
} 
indicate that an increase in industrialization increases non-renewable energy use by $0.389 \%$, and renewable energy use by $0.125 \%$. The effect of the share of services in GDP on non-renewable energy use and renewable energy use is positive and significant at $10 \%$ and $5 \%$ levels, respectively.

Table 5: Coefficients of CCE Estimates for Non-renewable and Renewable Energy Use Models

\begin{tabular}{lll}
\hline Dependent Variables & Non-renewable energy use & Renewable energy use \\
\hline LP & $1.763(1.82)^{*}$ & $0.710(1.75)^{*}$ \\
LA & $0.537(3.18)^{* * *}$ & $0.268(1.89)^{* *}$ \\
LIND & $0.389(2.99)^{* * *}$ & $0.125(1.91)^{* *}$ \\
LS & $0.536(2.25)^{* *}$ & $0.294(2.12)^{* *}$ \\
LU & $0.821(2.15)^{* *}$ & $1.154(0.24)$ \\
LPD & $-0.482(-1.94)^{* *}$ & $-0.437(-0.80)$
\end{tabular}

Note: Related-statistics are presented in parentheses. ***,** and * indicate that the test statistic is significant at $1 \%, 5 \%$ and $10 \%$ levels, respectively.

The estimated coefficients suggest that an increase in the share of services in GDP is associated with $0.536 \%$ increase in the non-renewable energy use and $0.294 \%$ increase in the renewable energy use. It is worth noting that the impacts of economic growth, industrialization and the share of services in GDP on non-renewable energy consumption are greater than that on the renewable energy use. It appears that, although the benefits of clean and renewable energy are evident, yet the displacement of fossil fuel usage by renewable energy resources has occurred at a very low rate. The positive relationship between GDP per capita, the share of industry and services in GDP and energy consumption, is also found in previous studies that have investigated these three factors simultaneously, controlling for urbanization (Poumanywong and Kaneko 2010; Zhang and Lin, 2012). The relationship between urbanization and energy consumption is as expected: positive but significant only for non-renewable energy consumption. Similarly, the effect of population density on both non-renewable and renewable energy use are negative, however, significant only for non-renewable energy use.

It appears that, although the use of renewable energy sources (hydropower, biomass, biofuels, wind, geothermal, and solar), particularly for electricity generation, has increased recently in developed countries, the main energy source used by 
humans is still non-renewable fossil fuels. The use of renewable sources is also limited by the fact that they are not always available. An increase in non-renewable energy use due to urbanization can also be explained by following arguments in Poumanyvong et al. (2012) who reveal that the impact of urbanization on transport and road energy use is high in high income group countries (higher than the low and middle income groups). On the one hand, while energy consumption in motorised individual passenger traffic is up to 10 times as high as consumption in a wellorganised and demand-oriented public transport system, people in developed countries depend heavily on the individual automobiles for their daily trips (Weiler, 2006; Poumanyvong et al., 2012). On the other hand, transport is heavily dependent on fossil fuels (97\% of transport energy is based on oil (Weiler, 2006)). Therefore, all the evidence supports the positive association between urbanization and nonrenewable energy consumption in OECD countries.

The results obtained in this study may not be exactly comparable with those of other studies that use aggregate energy consumption. However, considering energy consumption regardless of energy type, the findings can be compared with previous studies. The positive link between urbanization and energy consumption is supported by York (2007), Liddle and Lung (2010) and Poumanywong and Kaneko (2010) who also find that urbanization influences energy consumption positively in developed countries. Likewise, Jones (1991), Parikh and Shukla (1995), Imai (1997), York et al. (2003b), and Mishra (2009) achieve similar results for different countries.

As mentioned earlier, the linkage between population density and nonrenewable energy use is significant, while the relationship between population density and renewable energy use is insignificant. The long-run relationship between population density and non-renewable energy use shows that the effect of population density on non-renewable energy use is negative and statistically significant at $5 \%$ level. The results indicate that a $1 \%$ increase in population density leads to $0.482 \%$ decrease in non-renewable energy consumption in the long run. This result supports the hypothesis implying that increasing density reduces energy use. This finding is consistent with an early study by Newman and Kenworthy (1989) and Larivière and Lafrance (1999) who find a negative relationship between population density and energy use in high income countries and Canada, respectively. The finding is also in line with Chen et al. (2008) who reveal that urban density has a negative effect on household energy consumption in Chinese cities. 
Population density can reduce environmental impact through clustering a mixture of residential, office, retail, and outdoor recreational uses together, thereby shrinking travel distances and encouraging walking, cycling and public transport that reduces the use of fossil fuels. Despite urbanization, greater density improves the economics of public transport systems, and thereby results in lower energy use per passenger-kilometre of travel in such places. Furthermore, another attribute of high population density is through its effect on building sectors. Multi-family housing allows for more efficient energy use than single-family homes. For instance, energy use in places like New York City or Philadelphia is significantly less than that in Dallas or Phoenix, which have dispersed settlement patterns (Darmstadter, 2001).

Although the limited number of studies so far shows that population density decreases energy consumption in general, the results of this study indicating that population density reduces non-renewable energy consumption in particular, can shed further light on the existing literature. Moreover, this finding helps policy makers to improve urban planning that can finally make a substantial contribution to climate change mitigation. As an energy management policy, controlling disparity of population and the level of urbanization, which are associated with increased demands for energy, can result in a significant reduction in pollutant emissions.

\subsection{Panel Causality Analysis}

In this section short-run and long-run Granger causality is analysed. Table 6 and Table 7 display the results of the panel error correction for non-renewable and renewable energy use models, respectively. The short-run results of the explanatory variables effects on non-renewable energy use indicate that from the demographic variables, including total population, urbanization and population density, only total population has a significant impact on non-renewable energy consumption. The impact of GDP per capita on non-renewable energy use is positive and significant at the $1 \%$ level in the short run. The relationship between the share of services in GDP and non-renewable energy use is positive and significant, whereas the relationship between the share of industry in GDP and non-renewable energy use is insignificant. The effects of the same explanatory variables on renewable energy use (Table 7) indicate that none of the studied independent factors has a significant impact on renewable energy consumption in the short run. 
In relation to the short-run effects of non-renewable and renewable energy consumption on the other variables, the results from Table 6 and Table 7 respectively, illustrate that while non-renewable energy use has a statistically significant impact on total population and population density, renewable energy use does not show any significant relationship with any of the variables. The short run causality directions show that there is bidirectional causality between non-renewable energy use and total population, unidirectional causality from GDP per capita to non-renewable energy use, unidirectional causality from the share of services in GDP to non-renewable energy use, and unidirectional causality from non-renewable energy use to population density.

A neutral relationship between urbanization and energy consumption (for both renewable and non-renewable) in this study is consistent with Halicioglu (2007) who also finds no Granger causality between urbanization and energy consumption for Turkey in the short run. However, this result contrasts with the unidirectional causality running from urbanization to energy consumption found by Liu (2009) and Mishra et al (2009) for China and for the Pacific Island countries, respectively. In contrast, Shahbaz and Lean (2012) demonstrate a unidirectional causality running from energy consumption to urbanization for Tunisia.

In relation to the long-run causality results, the error correction terms in both nonrenewable and renewable energy use equations are negative and significant, revealing that there is Granger causality from total population, GDP per capita, the share of industry in GDP, the share of services in GDP, urbanization and population density to non-renewable energy use and to renewable energy use in the long run. The coefficients of the error correction terms also suggest that the deviation of nonrenewable and renewable energy consumption from short run to the long run is corrected by $91 \%$ and $92 \%$ respectively each year; and convergence to equilibrium after a shock to both non-renewable and renewable energy consumption takes one year (Table 6 and Table 7). 
Table 6: Panel Causality Test for Non-renewable Energy Use Model

\begin{tabular}{|c|c|c|c|c|c|c|c|c|}
\hline \multirow[t]{3}{*}{$\begin{array}{l}\text { Dependent } \\
\text { Variables } \\
\end{array}$} & \multicolumn{7}{|c|}{ Source of causation (independent variable) } & \multirow{3}{*}{$\begin{array}{l}\text { Long run } \\
\text { ECT }\end{array}$} \\
\hline & \multicolumn{7}{|l|}{ Short run } & \\
\hline & $\Delta \mathrm{LN}$ & $\Delta \mathrm{LP}$ & $\Delta \mathrm{LA}$ & $\Delta$ LIND & $\Delta \mathrm{LS}$ & $\Delta \mathrm{LU}$ & $\Delta \mathrm{LPD}$ & \\
\hline$\Delta \mathrm{LN}$ & - & $\begin{array}{l}2.207 \\
(1.67)^{*}\end{array}$ & $\begin{array}{l}0.137 \\
(2.78) * * *\end{array}$ & $\begin{array}{l}0.044 \\
(0.67)\end{array}$ & $\begin{array}{l}0.190 \\
(1.69)^{*}\end{array}$ & $\begin{array}{l}0.680 \\
(0.44)\end{array}$ & $\begin{array}{l}0.215 \\
(0.37)\end{array}$ & $\begin{array}{l}-0.914 \\
(-12.61) * * *\end{array}$ \\
\hline$\Delta \mathrm{LP}$ & $\begin{array}{l}0.004 \\
(1.88)^{* *}\end{array}$ & - & $\begin{array}{l}-0.003 \\
(-1.49)\end{array}$ & $\begin{array}{l}0.003 \\
(1.25)\end{array}$ & $\begin{array}{l}-0.005 \\
(-0.99)\end{array}$ & $\begin{array}{l}0.081 \\
(0.93)\end{array}$ & $\begin{array}{l}0.054 \\
(1.87)^{* *}\end{array}$ & $\begin{array}{l}-0.006 \\
(-1.73)^{*}\end{array}$ \\
\hline$\Delta \mathrm{LA}$ & $\begin{array}{l}0.002 \\
(0.10)\end{array}$ & $\begin{array}{l}0.919 \\
(1.79)^{*}\end{array}$ & - & $\begin{array}{l}0.183 \\
(4.00)^{* * *}\end{array}$ & $\begin{array}{l}0.168 \\
(3.03)^{* * *}\end{array}$ & $\begin{array}{l}0.735 \\
(1.19)\end{array}$ & $\begin{array}{l}0.374 \\
(0.93)\end{array}$ & $\begin{array}{l}0.248 \\
(4.49)^{* * *}\end{array}$ \\
\hline$\Delta$ LIND & $\begin{array}{l}0.003 \\
(0.08)\end{array}$ & $\begin{array}{l}1.021 \\
(1.84)^{*}\end{array}$ & $\begin{array}{l}0.250 \\
(4.47)^{* * *}\end{array}$ & - & $\begin{array}{l}1.088 \\
(15.05)^{* * *}\end{array}$ & $\begin{array}{l}2.429 \\
(1.86)^{*}\end{array}$ & $\begin{array}{l}1.09 \\
(2.52)^{*}\end{array}$ & $\begin{array}{l}-0.019 \\
(0.33)\end{array}$ \\
\hline$\Delta \mathrm{LS}$ & $\begin{array}{l}-0.011 \\
(-0.83)\end{array}$ & $\begin{array}{l}0.200 \\
(0.63)\end{array}$ & $\begin{array}{l}0.208 \\
(6.49)^{* * *}\end{array}$ & $\begin{array}{l}0.401 \\
(16.50) * * *\end{array}$ & - & $\begin{array}{l}0.863 \\
(1.13)\end{array}$ & $\begin{array}{l}0.765 \\
(3.10)^{* * *}\end{array}$ & $\begin{array}{l}-0.006 \\
(-0.19)\end{array}$ \\
\hline
\end{tabular}

Note: $z$-statistics are presented in parentheses. $*^{* *}, * *$ and $*$ indicate that the test statistic is significant at $1 \%, 5 \%$ and $10 \%$ levels respectively. The optimal lag length for the variables is two and determined by the Akaike and the Schwarz Information Criteria. ECT indicates the estimated error correction term. 
Table 7: Panel Causality Test for Renewable Energy Use Model

\begin{tabular}{|c|c|c|c|c|c|c|c|c|}
\hline \multirow[t]{3}{*}{$\begin{array}{l}\text { Dependent } \\
\text { Variables }\end{array}$} & \multicolumn{7}{|c|}{ Source of causation (independent variable) } & \multirow{3}{*}{$\begin{array}{l}\text { Long run } \\
\text { ECT }\end{array}$} \\
\hline & \multicolumn{7}{|l|}{ Short run } & \\
\hline & $\Delta \mathrm{LR}$ & $\Delta \mathrm{LP}$ & $\Delta \mathrm{LA}$ & $\Delta$ LIND & $\Delta \mathrm{LS}$ & $\Delta \mathrm{LU}$ & $\Delta \mathrm{LPD}$ & \\
\hline$\Delta \mathrm{LR}$ & - & $\begin{array}{l}0.166 \\
(0.04)\end{array}$ & $\begin{array}{l}-0.014 \\
(-0.06)\end{array}$ & $\begin{array}{l}0.196 \\
(0.79)\end{array}$ & $\begin{array}{l}0.294 \\
(0.72)\end{array}$ & $\begin{array}{l}-2.382 \\
(-0.53)\end{array}$ & $\begin{array}{l}1.270 \\
(0.43)\end{array}$ & $\begin{array}{l}-0.922 \\
(-13.22) * * *\end{array}$ \\
\hline$\Delta \mathrm{LP}$ & $\begin{array}{l}-0.000 \\
(-0.45)\end{array}$ & - & $\begin{array}{l}-0.004 \\
(-1.17)\end{array}$ & $\begin{array}{l}0.003 \\
(1.32)\end{array}$ & $\begin{array}{l}-0.005 \\
(-0.90)\end{array}$ & $\begin{array}{l}0.080 \\
(0.89)\end{array}$ & $\begin{array}{l}0.062 \\
(2.14)^{* *}\end{array}$ & $\begin{array}{l}0.000 \\
(0.10)\end{array}$ \\
\hline$\Delta \mathrm{LA}$ & $\begin{array}{l}-0.001 \\
(-0.21)\end{array}$ & $\begin{array}{l}0.746 \\
(1.78)^{*}\end{array}$ & - & $\begin{array}{l}0.204 \\
(4.06)^{* * *}\end{array}$ & $\begin{array}{l}0.204 \\
(3.33)^{* * *}\end{array}$ & $\begin{array}{l}0.347 \\
(0.49)\end{array}$ & $\begin{array}{l}0.472 \\
(1.07)\end{array}$ & $\begin{array}{l}0.001 \\
(0.15)\end{array}$ \\
\hline$\Delta$ LIND & $\begin{array}{l}0.003 \\
(0.89)\end{array}$ & $\begin{array}{l}0.995 \\
(1.82)^{*}\end{array}$ & $\begin{array}{l}0.235 \\
(4.55)^{* * *}\end{array}$ & - & $\begin{array}{l}1.082 \\
(15.00)^{* * *}\end{array}$ & $\begin{array}{l}3.075 \\
(2.35)^{* *}\end{array}$ & $\begin{array}{l}0.931 \\
(2.18)^{* *}\end{array}$ & $\begin{array}{l}0.004 \\
(0.41)\end{array}$ \\
\hline$\Delta \mathrm{LS}$ & $\begin{array}{l}0.000 \\
(0.24)\end{array}$ & $\begin{array}{l}0.274 \\
(0.88)\end{array}$ & $\begin{array}{l}0.180 \\
(6.11)^{* * *}\end{array}$ & $\begin{array}{l}0.385 \\
(15.83)^{* * *}\end{array}$ & - & $\begin{array}{l}0.996 \\
(1.30)\end{array}$ & $\begin{array}{l}0.766 \\
(3.13)^{* * *}\end{array}$ & $\begin{array}{l}0.003 \\
(0.52)\end{array}$ \\
\hline
\end{tabular}

Note: $z$-statistics are presented in parentheses. $* * * * *$ and $*$ indicate that the test statistic is significant at $1 \%, 5 \%$ and $10 \%$ levels respectively. The optimal lag length for the variables is two and determined by the Akaike and the Schwarz Information Criteria. ECT indicates the estimated error correction term. 


\section{Conclusion and Policy Implications}

This article contributes to previous research on the determinants of non-renewable and renewable energy consumption by incorporating urbanization into the stochastic model, STIRPAT. This model is used here in predicting impact of urbanization on both types of energy use and estimating causal effects. The use of highly flexible panel techniques has allowed us to better characterise the order of integration of variables used in the model and thereby provide more robust cointegration and causality analyses compared to earlier studies. More specifically we employed recently developed unit root test by Carrion-i-Silvestre et al. (2005) and panel cointegration test by Westerlund (2006) which account for structural breaks and cross sectional dependence. Accounting for cross-sectional dependence, we find that urbanization has a positive and significant impact on non-renewable energy use in OECD countries, whereas the effect of urbanization is not so significant on renewable energy use. In relation to the effect of population density, a significant negative relationship is found between population density and non-renewable energy consumption. In addition, Granger causality results indicate that there is unidirectional causality from non-renewable energy use to population density in the short term. However, no causal linkage is found between urbanization and non-renewable energy use. Likewise, no causal direction is seen between renewable energy use and any of the demographic factors in the short run. The coefficients of the dynamic error correction terms in both non-renewable and renewable energy use models are negative and significant, implying that the variables adjust towards a long run equilibrium level, after a shock occurs.

The absence of a significant association between renewable energy use and urbanization and also between renewable energy use and population density illustrate that although the use of renewable energy sources has increased recently in developed countries, the main energy source available for people to use is still non-renewable fossil fuels. In the case of the positive relationship between urbanization and nonrenewable energy use, it can be said that economic development and increasing incomes which are followed by urbanization, leads to changes in consumer needs, which in turns results in an increasing energy consumption. Moreover, urbanization through its increasing effect on transport energy demand increases the use of nonrenewable sources. Therefore, as an energy management policy, controlling disparity 
of population and the level of urbanization may result in a significant reduction in energy consumption. Moreover, the results of this study indicate that population density reduces non-renewable energy consumption can help policy makers improve urban planning that can finally make a substantial contribution to climate change mitigation. 


\section{Appendix}

Appendix Table 1: Multicollinearity test: VIF Values

\begin{tabular}{|c|c|c|}
\hline Variable & VIF & $1 / \mathrm{VIF}$ \\
\hline LS & 4.60 & 0.217387 \\
\hline LIND & 2.97 & 0.336490 \\
\hline LA & 2.12 & 0.471891 \\
\hline LP & 1.31 & 0.764511 \\
\hline LU & 1.30 & 0.767854 \\
\hline LPD & 1.20 & 0.833617 \\
\hline Mean VIF & 2.25 & \\
\hline
\end{tabular}

Note: The VIF values are all below 10, implying that there is no multicollinearity.

Appendix Table 2: Estimated breaks for individual countries

\begin{tabular}{|c|c|c|c|c|c|c|c|}
\hline \multirow[t]{2}{*}{ Countries } & \multirow[t]{2}{*}{ Variables } & \multirow{2}{*}{$\begin{array}{c}\text { Number of } \\
\text { breaks }\end{array}$} & \multicolumn{5}{|c|}{ Dates of breaks } \\
\hline & & & 1 & 2 & 3 & 4 & 5 \\
\hline \multirow[t]{6}{*}{ Australia } & LP & 2 & 1981 & 1998 & & & \\
\hline & LA & 4 & 1985 & 1989 & 1994 & 2001 & \\
\hline & LIND & 3 & 1982 & 1996 & 2000 & & \\
\hline & LS & 2 & 1983 & 1994 & & & \\
\hline & LU & 2 & 1986 & 1993 & & & \\
\hline & LPD & 1 & 1981 & & & & \\
\hline \multirow[t]{6}{*}{ Austria } & LP & 3 & 1982 & 1989 & 1993 & & \\
\hline & LA & 4 & 1982 & 1991 & 1998 & 2002 & \\
\hline & LIND & 2 & 1983 & 1992 & & & \\
\hline & $\mathrm{LS}$ & 1 & 1987 & & & & \\
\hline & LU & 3 & 1980 & 1987 & 1999 & & \\
\hline & LPD & 2 & 1981 & 1998 & & & \\
\hline \multirow[t]{6}{*}{ Belgium } & LP & 2 & 1983 & 1989 & & & \\
\hline & LA & 3 & 1988 & 1996 & 2001 & & \\
\hline & LIND & 2 & 1989 & 2003 & & & \\
\hline & LS & 2 & 1983 & 1997 & & & \\
\hline & LU & 1 & 1991 & & & & \\
\hline & LPD & 2 & 1988 & 1998 & & & \\
\hline \multirow[t]{6}{*}{ Canada } & LP & 2 & 1984 & 1999 & & & \\
\hline & LA & 2 & 1981 & 1997 & & & \\
\hline & LIND & 3 & 1984 & 1995 & 2002 & & \\
\hline & LS & 2 & 1986 & 1998 & & & \\
\hline & LU & 3 & 1986 & 1996 & 2000 & & \\
\hline & LPD & 1 & 1987 & & & & \\
\hline \multirow[t]{4}{*}{ Chile } & LP & 2 & 1984 & 1993 & & & \\
\hline & LA & 2 & 1986 & 1999 & & & \\
\hline & LIND & 3 & 1983 & 1994 & 2003 & & \\
\hline & LS & 4 & 1980 & 1989 & 1993 & 2004 & \\
\hline
\end{tabular}




\begin{tabular}{|c|c|c|c|c|c|c|c|}
\hline \multirow[t]{2}{*}{ Countries } & \multirow[t]{2}{*}{ Variables } & \multirow{2}{*}{$\begin{array}{c}\text { Number of } \\
\text { breaks }\end{array}$} & \multicolumn{5}{|c|}{ Dates of breaks } \\
\hline & & & 1 & 2 & 3 & 4 & 5 \\
\hline \multirow{8}{*}{ Denmark } & $\mathrm{LU}$ & 2 & 1985 & 1998 & & & \\
\hline & LPD & 2 & 1987 & 1994 & & & \\
\hline & LP & 2 & 1987 & 1994 & & & \\
\hline & LA & 3 & 1982 & 1994 & 2000 & & \\
\hline & LIND & 3 & 1984 & 1992 & 1999 & & \\
\hline & LS & 1 & 1988 & & & & \\
\hline & LU & 2 & 1986 & 1995 & & & \\
\hline & LPD & 1 & 1983 & & & & \\
\hline \multirow[t]{6}{*}{ Finland } & LP & 2 & 1985 & 1996 & & & \\
\hline & LA & 3 & 1984 & 1997 & 2001 & & \\
\hline & LIND & 2 & 1983 & 1998 & & & \\
\hline & LS & 3 & 1980 & 1989 & 1996 & & \\
\hline & LU & 2 & 1991 & 2002 & & & \\
\hline & LPD & 1 & 1989 & & & & \\
\hline \multirow[t]{6}{*}{ France } & LP & 2 & 1982 & 1998 & & & \\
\hline & LA & 2 & 1983 & 1999 & & & \\
\hline & LIND & 2 & 1989 & 2001 & & & \\
\hline & $\mathrm{LS}$ & 2 & 1988 & 2002 & & & \\
\hline & LU & 3 & 1981 & 1988 & 1995 & & \\
\hline & LPD & 2 & 1983 & 1991 & & & \\
\hline \multirow{6}{*}{ Germany } & LP & 2 & 1985 & 1997 & & & \\
\hline & LA & 4 & 1984 & 1992 & 1998 & 2003 & \\
\hline & LIND & 3 & 1985 & 1996 & 2001 & & \\
\hline & $\mathrm{LS}$ & 1 & 1989 & & & & \\
\hline & LU & 2 & 1984 & 1993 & & & \\
\hline & LPD & 2 & 1984 & 1992 & & & \\
\hline \multirow[t]{6}{*}{ Greece } & LP & 1 & 1986 & & & & \\
\hline & LA & 3 & 1983 & 1997 & 2002 & & \\
\hline & LIND & 3 & 1984 & 1996 & 2001 & & \\
\hline & LS & 3 & 1982 & 1991 & 2000 & & \\
\hline & LU & 2 & 1983 & 1994 & & & \\
\hline & LPD & 2 & 1983 & 1996 & & & \\
\hline \multirow[t]{6}{*}{ Hungary } & LP & 2 & 1985 & 1994 & & & \\
\hline & LA & 1 & 1985 & & & & \\
\hline & LIND & 2 & 1983 & 1994 & & & \\
\hline & LS & 2 & 1982 & 1998 & & & \\
\hline & LU & 3 & 1982 & 1997 & 2000 & & \\
\hline & LPD & 2 & 1982 & 1997 & & & \\
\hline \multirow[t]{6}{*}{ Iceland } & LP & 1 & 1994 & & & & \\
\hline & LA & 3 & 1984 & 1992 & 1999 & & \\
\hline & LIND & 2 & 1987 & 1997 & & & \\
\hline & LS & 2 & 1984 & 1996 & & & \\
\hline & LU & 2 & 1983 & 1992 & & & \\
\hline & LPD & 1 & 1993 & & & & \\
\hline Ireland & LP & 2 & 1985 & 1997 & & & \\
\hline
\end{tabular}




\begin{tabular}{|c|c|c|c|c|c|c|c|}
\hline \multirow[t]{2}{*}{ Countries } & \multirow[t]{2}{*}{ Variables } & \multirow{2}{*}{$\begin{array}{c}\text { Number of } \\
\text { breaks }\end{array}$} & \multicolumn{5}{|c|}{ Dates of breaks } \\
\hline & & & 1 & 2 & 3 & 4 & 5 \\
\hline & LA & 4 & 1982 & 1989 & 1996 & 2001 & \\
\hline & LIND & 3 & 1985 & 1997 & 2003 & & \\
\hline & LS & 2 & 1984 & 1997 & & & \\
\hline & LU & 3 & 1981 & 1987 & 1998 & & \\
\hline & LPD & 2 & 1988 & 1995 & & & \\
\hline \multirow[t]{6}{*}{ Italy } & LP & 1 & 1991 & & & & \\
\hline & LA & 4 & 1983 & 1990 & 1998 & 2003 & \\
\hline & LIND & 3 & 1983 & 1989 & 1999 & 2001 & \\
\hline & $\mathrm{LS}$ & 2 & 1984 & 1994 & & & \\
\hline & LU & 3 & 1982 & 1989 & 1994 & & \\
\hline & LPD & 2 & 1982 & 1987 & & & \\
\hline \multirow[t]{6}{*}{ Japan } & LP & 3 & 1981 & 1988 & 1991 & & \\
\hline & LA & 2 & 1984 & 1998 & & & \\
\hline & LIND & 3 & 1986 & 1995 & 2002 & & \\
\hline & LS & 2 & 1988 & 2000 & & & \\
\hline & $\mathrm{LU}$ & 2 & 1989 & 1996 & & & \\
\hline & LPD & 1 & 1989 & & & & \\
\hline \multirow[t]{6}{*}{ South Korea } & LP & 3 & 1985 & 1991 & 1997 & & \\
\hline & LA & 2 & 1988 & 2000 & & & \\
\hline & LIND & 3 & 1987 & 1997 & 2001 & & \\
\hline & LS & 2 & 1984 & 1994 & & & \\
\hline & LU & 1 & 1994 & & & & \\
\hline & LPD & 2 & 1989 & 1995 & & & \\
\hline \multirow[t]{6}{*}{ Luxembourg } & LP & 2 & 1986 & 1996 & & & \\
\hline & LA & 3 & 1981 & 1989 & 1998 & & \\
\hline & LIND & 2 & 1987 & 2000 & & & \\
\hline & LS & 2 & 1983 & 1999 & & & \\
\hline & LU & 2 & 1987 & 1994 & & & \\
\hline & LPD & 1 & 1992 & & & & \\
\hline \multirow[t]{6}{*}{ Mexico } & LP & 2 & 1981 & 1997 & & & \\
\hline & LA & 2 & 1991 & 2002 & & & \\
\hline & LIND & 2 & 1995 & 2001 & & & \\
\hline & LS & 2 & 1984 & 1995 & & & \\
\hline & $\mathrm{LU}$ & 2 & 1989 & 1994 & & & \\
\hline & LPD & 2 & 1989 & 1997 & & & \\
\hline \multirow[t]{6}{*}{ Netherlands } & LP & 3 & 1984 & 1988 & 1992 & & \\
\hline & LA & 2 & 1983 & 1997 & & & \\
\hline & LIND & 2 & 1983 & 1999 & & & \\
\hline & LS & 2 & 1993 & 2000 & & & \\
\hline & LU & 1 & 1997 & & & & \\
\hline & LPD & 2 & 1987 & 1997 & & & \\
\hline \multirow[t]{4}{*}{ New Zealand } & LP & 2 & 1989 & 1994 & & & \\
\hline & LA & 3 & 1983 & 1997 & 2000 & & \\
\hline & LIND & 2 & 1986 & 1994 & 2002 & & \\
\hline & LS & 2 & 1983 & 1991 & & & \\
\hline
\end{tabular}




\begin{tabular}{|c|c|c|c|c|c|c|c|}
\hline \multirow[t]{2}{*}{ Countries } & \multirow[t]{2}{*}{ Variables } & \multirow{2}{*}{$\begin{array}{l}\text { Number of } \\
\text { breaks }\end{array}$} & \multicolumn{5}{|c|}{ Dates of breaks } \\
\hline & & & 1 & 2 & 3 & 4 & 5 \\
\hline & LU & 2 & 1981 & 1986 & & & \\
\hline & LPD & 1 & 1982 & & & & \\
\hline \multirow[t]{6}{*}{ Norway } & $\mathrm{LP}$ & 2 & 1984 & 1991 & & & \\
\hline & LA & 4 & 1984 & 1989 & 1996 & 2004 & \\
\hline & LIND & 2 & 1983 & 1995 & & & \\
\hline & LS & 1 & 1997 & & & & \\
\hline & LU & 2 & 1984 & 1989 & & & \\
\hline & LPD & 2 & 1982 & 1989 & & & \\
\hline \multirow[t]{6}{*}{ Poland } & LP & 2 & 1989 & 1996 & & & \\
\hline & LA & 3 & 1982 & 1989 & 1994 & & \\
\hline & LIND & 4 & 1985 & 1989 & 1992 & 2001 & \\
\hline & LS & 2 & 1987 & 1995 & & & \\
\hline & $\mathrm{LU}$ & 2 & 1987 & 1992 & & & \\
\hline & LPD & 2 & 1986 & 1993 & & & \\
\hline \multirow[t]{6}{*}{ Portugal } & $\mathrm{LP}$ & 2 & 1985 & 1999 & & & \\
\hline & LA & 3 & 1987 & 1991 & 2003 & & \\
\hline & LIND & 4 & 1986 & 1989 & 1994 & 2001 & \\
\hline & LS & 2 & 1985 & 1990 & & & \\
\hline & LU & 1 & 1986 & & & & \\
\hline & LPD & 2 & 1989 & 1991 & & & \\
\hline \multirow[t]{6}{*}{ Spain } & LP & 3 & 1987 & 1990 & 1998 & & \\
\hline & LA & 2 & 1989 & 1993 & 2001 & & \\
\hline & LIND & 2 & 1984 & 1998 & & & \\
\hline & $\mathrm{LS}$ & 3 & 1982 & 1986 & 1997 & & \\
\hline & LU & 2 & 1988 & 1993 & & & \\
\hline & LPD & 1 & 1993 & & & & \\
\hline \multirow[t]{6}{*}{ Sweden } & LP & 2 & 1984 & 1996 & & & \\
\hline & LA & 4 & 1982 & 1987 & 1994 & 2003 & \\
\hline & LIND & 2 & 1983 & 1998 & & & \\
\hline & LS & 2 & 1983 & 1997 & & & \\
\hline & $\mathrm{LU}$ & 1 & 1986 & & & & \\
\hline & LPD & 2 & 1982 & 1987 & & & \\
\hline \multirow[t]{6}{*}{ Switzerland } & LP & 3 & 1987 & 1991 & 2002 & & \\
\hline & LA & 2 & 1986 & 1999 & & & \\
\hline & LIND & 4 & 1987 & 1997 & 2000 & 2004 & \\
\hline & LS & 2 & 1986 & 1991 & & & \\
\hline & $\mathrm{LU}$ & 2 & 1983 & 1993 & & & \\
\hline & LPD & 2 & 1985 & 1998 & & & \\
\hline \multirow[t]{6}{*}{ Turkey } & LP & 2 & 1989 & 1997 & & & \\
\hline & LA & 3 & 1984 & 1989 & 1994 & & \\
\hline & LIND & 2 & 1984 & 2000 & & & \\
\hline & LS & 2 & 1986 & 1989 & & & \\
\hline & LU & 2 & 1983 & 1983 & & & \\
\hline & LPD & 2 & 1982 & 1989 & & & \\
\hline UK & LP & 2 & 1983 & 1988 & & & \\
\hline
\end{tabular}




\begin{tabular}{|c|c|c|c|c|c|c|c|}
\hline \multirow[t]{2}{*}{ Countries } & \multirow[t]{2}{*}{ Variables } & \multirow{2}{*}{$\begin{array}{c}\text { Number of } \\
\text { breaks }\end{array}$} & \multicolumn{5}{|c|}{ Dates of breaks } \\
\hline & & & 1 & 2 & 3 & 4 & 5 \\
\hline \multirow{11}{*}{ US } & LA & 3 & 1987 & 1993 & 2001 & & \\
\hline & LIND & 2 & 1989 & 1997 & & & \\
\hline & $\mathrm{LS}$ & 2 & 1984 & 1997 & & & \\
\hline & LU & 2 & 1986 & 1994 & & & \\
\hline & LPD & 1 & 1986 & & & & \\
\hline & LP & 2 & 1989 & 1996 & & & \\
\hline & LA & 2 & 1984 & 1997 & & & \\
\hline & LIND & 2 & 1989 & 2000 & & & \\
\hline & $\mathrm{LS}$ & 2 & 1993 & 1998 & & & \\
\hline & LU & 1 & 1983 & & & & \\
\hline & LPD & 2 & 1985 & 1989 & & & \\
\hline
\end{tabular}

Appendix Table 3: Diagnostic tests for non-renewable and renewable energy use models

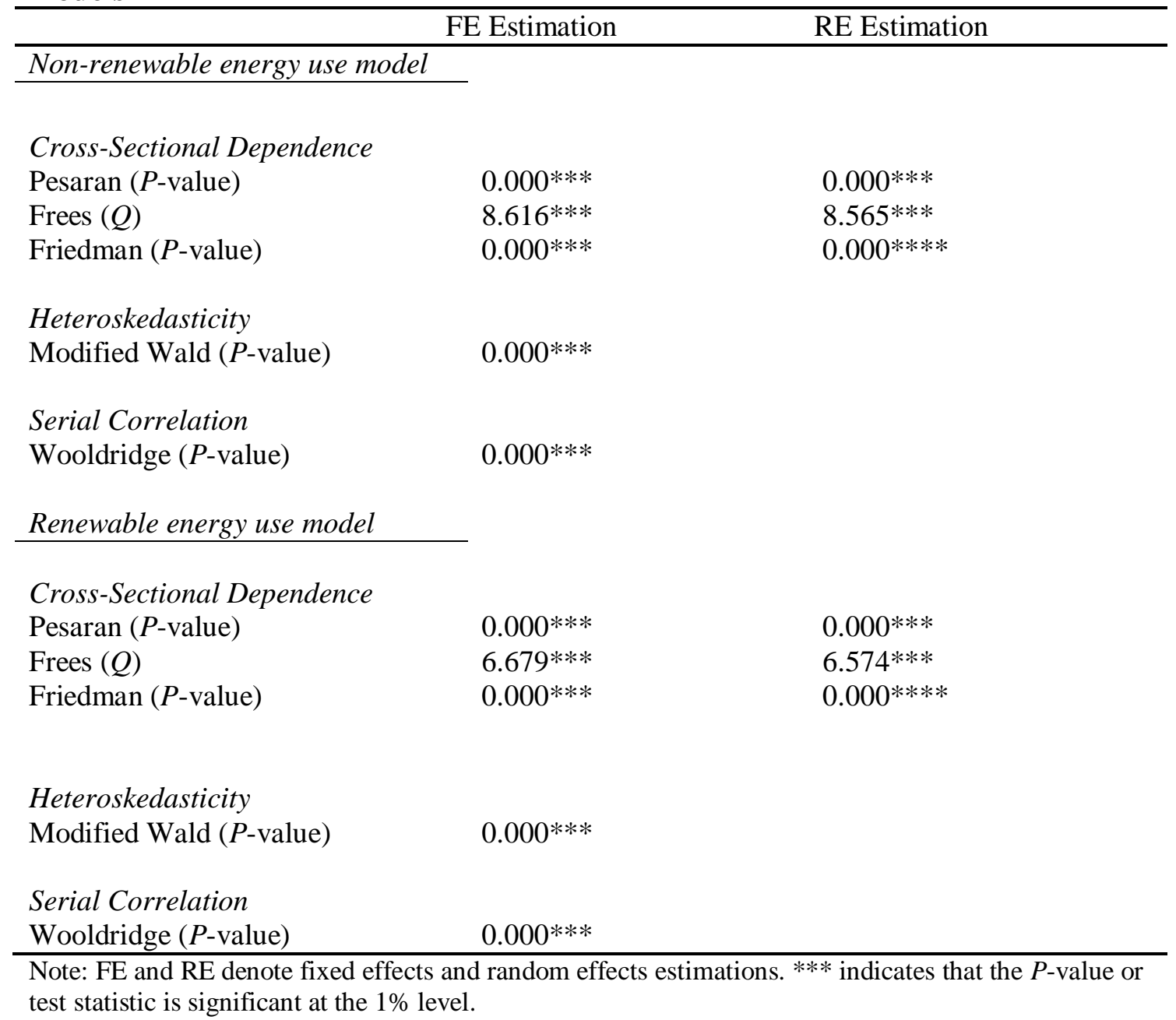




\section{References}

Arellano, M. and S. Bond, 1991. Some tests of specification for panel data: Monte Carlo evidence and an application to employment equations, Review of Economic Studies, 58: 277-297.

Blundell, R. W. and S. R. Bond. 1998. Initial Conditions and Moment Restrictions in Dynamic Panel Data Models. Econometrics 87:115-143.

Breitung, J. 2000. The Local Power of Some Unit Root Tests for Panel Data. Advances in Econometrics 15:161-178.

Carrión-i-Silvestre, J. L., T. Del Barrio, and E. López-Bazo. 2005. Breaking the panels. An application to the GDP per capita, Econometrics Journal 8:159175.

Chen, H., B. Jia, and S. S. Y. Lau. 2008. Sustainable urban form for Chinese compact cities: Challenges of a rapid urbanized economy. Habitat International 32 (1):28-40.

Darmstadter, J. 2001. The Energy-CO2 Connection: A Review of Trends and Challenges. In Climate Change Economics and Policy. edited by M. A. Toman. Washington Resources for the Future.

Dickey, D. A. and W. A. Fuller. 1979. Distribution of the Estimators for Autoregressive Time Series with a Unit Root. American Statistical Association 74 (366):427-431.

Dietz, T. and E. A. Rosa. 1997. Effects of population and affluence on $\mathrm{CO}_{2}$ emissions. Proceedings of the National Academy of Sciences of the USA 94:175-179.

Ehrlich, P., and J. Holdren. 1971. Impact of population growth. Science 171:12121217.

Halicioglu, F. 2007. Residential electricity demand dynamics in Turkey. Energy Economics 29:199-210.

Hankey, S. and J. D. Marshall. 2010. Impacts of urban form on future US passengervehicle greenhouse gas emissions. EnergyPolicy 38 (9):4880-4887.

Holdren, J. P. and Ehrlich, P.R. (1974). Human population and the global environment. American Scientist, 62(3): 282-292.

Hsues, S., Hu, Y. and Tu, C (2013) Economic growth and financial development in Asian countries: A bootstrap panel Granger causality analysis, Economic Modelling, 32: 294-301.

IEA. 2009. Energy Balances of OECD Countries. CD-ROM. International Energy Agency (IEA), Paris.

Im, K., M. H. Pesaran, and Y. Shin. 2003. Testing for unit roots in heterogeneous panels. Journal of Econometrics 115 (1):53-74.

Imai, H. 1997. The effect of urbanization on energy consumption. Journal of Population Problems 53(2):43-49.

Islam, F., Shahbaz, M., Ahmed, A. U., and Alam, M. M. (2013) Financial development and energy consumption nexus in Malaysia: A multivariate time series analysis, Economic Modelling, 30: 435-441. 
Johansen, S. (1988), Statistical Analysis of Cointegration Vectors. Journal of Economic Dynamics and Control, 12(2-3): 231-254.

Jones, D. W. 1991. How urbanization affects energy-use in developing countries. Energy Policy 19 (7):621-629.

Jones, D. W. 2004. Urbanization and energy. Encyclopedia of Energy 6:329-335.

Kamal-Chaoui, Lamia and Alexis Robert, (2009) Competitive Cities and Climate Change, OECD Regional Development Working Papers No 2, 2009, OECD publishing, Publications, Paris.

Kapetanios, G., and M. H. Pesaran. 2007. Alternative Approaches to Estimation and Inference in Large Multifactor Panels: Small Sample Results with an Application to Modelling of Asset Returns, in Phillips, G., Tzavalis, E. (Eds.,), The Refinement of Econometric Estimation and Test Procedures: Finite Sample and Asymptotic Analysis, Cambridge University Press, Cambridge.

Larivière, I., and G. Lafrance. 1999. Modelling the electricity consumption of cities: effect of urban density. Energy Economics 21 (1):53-66.

Levin, A., C.-F. Lin, and C.S.J. Chu. 2002. Unit root tests in panel data: asymptotic and finite sample properties. Econometrics 108:1-24.

Liang, C., Lin, J. and Hsu, H. (2013) Reexamining the relationships between stock prices and exchange rates in ASEAN-5 using panel Granger causality approach, Economic Modelling, 32: 560-563.

Liddle, B. (2004). Demographic dynamics and per capita environmental impact: Using panel regressions and household decompositions to examine population and transport. Population and Environment 26(1):23-39.

Liddle, B. and S. Lung. 2010. Age-structure, urbanization, and climate change in developed countries: revisiting STIRPAT for disaggregated population and consumption-related environmental impacts. Population and Environment 31 (5):317-343.

Liu, Y. 2009.Exploring the relationship between urbanization and energy consumption in China using ARDL (autoregressive distributed lag) and FDM (factor decomposition model). Energy 34:1846-1854.

Lozano, S., and E. Gutiérrez. 2008. Non-parametric frontier approach to modelling the relationships among population, GDP, energy consumption and $\mathrm{CO}_{2}$ emissions. Ecological Economics 66 (4):687-699.

Maddala, G. S. and S. Wu. 1999. A Comparative Study of Unit Root Tests with Panel Data and a New Simple Test. Oxford Bulletin of Economics and Statistics 61:631-52.

Madlener, R., Y. Sunak. 2011. Impacts of urbanization on urban structures and energy demand: What can we learn for urban energy planning and urbanization management? Sustainable Cities and Society 1:45-53.

Martínez-Zarzoso, I., A. Bengochea-Morancho, and R. Morales-Lage. 2007. The impact of population on $\mathrm{CO}_{2}$ emissions: evidence from European countries. Environmental and Resource Economics 38 (4):497-512. 
Mindali, O., Raveh, A. \& Salomon, I. (2004) Urban Density and Energy Consumption: a New Look at Old Statistics. Transportation Research A, 38, 143-162.

Mishra, V., R. Smyth, and S. Sharma. 2009. The energy-GDP nexus: Evidence from a panel of Pacific Island countries. Resource and Energy Economics 31:210220.

Newman, P., J. Kenworthy 1989. Cities and Automobile Dependence: An International Sourcebook. Gower, Aldershot, UK.

O'Neill, B. C. X. Ren, L. Jiang and M. Dalton 2012. The effect of urbanization on energy use in India and China in the iPETS model. Energy Economics 34(3):S339-S345.

Parikh, J., and V. Shukla. 1995. Urbanization, energy use and greenhouse effects in economic development: Results from a cross-national study of developing countries. Global Environmental Change 5 (2):87-103.

Pesaran, M. H. 2006. Estimation and Inference in Large Heterogenous Panels with Multifactor Error Structure. Econometrica 74:967-1012.

Pesaran, M. H. and E. Tosetti 2011. Large panels with common factors and spatial correlation. Econometrics 161:182-202.

Phillips, P. C. B., and D. Sul. 2007. Bias in dynamic panel estimation with fixed effects, incidental trends and cross section dependence. Journal of Econometrics 137 (1):162-188.

Phillips, P. C. B. and P. Perron. 1988. Testing for a Unit Root in Time Series Regression. Biometrika 75: 335-346.

Poumanyvong, P., and S. Kaneko. 2010. Does urbanization lead to less energy use and lower $\mathrm{CO} 2$ emissions? A cross-country analysis. Ecological Economics 70 (2):434-444.

Poumanyvong, P., S. Kanekoa and S. Dhakal. 2012. Impacts of urbanization on national transport and road energy use: Evidence from low, middle and high income countries. Energy Policy 46:268-277.

Rodrigue, J.-P., C. Comtois, B. Slack. 2006. The Geography of Transport Systems. Routledge, NewYork.

Schurr S. H., J. Darmstadter, H. Perry, W. Ramsay and M. Russell. 1979. Energy in America's Future, The Choices Before Us. The Johns Hopkins University Press for Resources for the Future, Baltimore.

Shahbaz, M. Zeshan, M. and Afza, T. (2012) Is energy consumption effective to spur economic growth in Pakistan? New evidence from bounds test to level relationships and Granger causality tests, Economic Modelling, 29: 23102319.

Shahbaz, M., and H. Lean. 2012. Does financial development increase energy consumption? The role of industrialization and urbanization in Tunisia. Energy Policy 40 (0):473-479.

Shen, L., S. Cheng, A. J. Gunson and H. Wan 2005. Urbanization, sustainability and the utilization of energy and mineral resources in China. Cities 22:287-302. 
Shi, A. 2003. The impact of population pressure on global carbon dioxide emissions, 1975-1996: evidence from pooled cross-country data. Ecological Economics 44 (1):24-42.

Wei, B., H.Yagita, A. Inaba and M. Sagisaka 2003. Urbanization impact on energy demand and $\mathrm{CO}_{2}$ emission in China. Journal of Chongqing University 2:4650 .

Weiler, F. (2006). Transport, Energy, and Global Climate Change Improving Energy Efficiency for Sustainable Mobility. Policy Papers of KfW Entwicklungsbank.

Westerlund, J., 2006. Testing for panel cointegration with multiple structural breaks. Oxford Bulletin of Economics and Statistics 68, 101-132.

Westerlund, J. 2007. Testing for error correction in panel data. Oxford Bulletin of Economics and Statistics 69:709-748.

York, R., E. A. Rosa and T. Dietz. 2003a. Footprints on the Earth: The Environmental Consequences of Modernity. American Sociological Review 68 (2):279-300.

York, R, E. A. Rosa, and T. Dietz. 2003b. STIRPAT, IPAT and ImPACT: analytic tools for unpacking the driving forces of environmental impacts. Ecological Economics 46 (3):351-365.

York, R. 2007. Demographic trends and energy consumption in European Union Nations, 1960-2025. Social Science Research 36 (3):855-872.

Zhang, C., and Y. Lin. 2012. Panel estimation for urbanization, energy consumption and CO2 emissions: A regional analysis in China. Energy Policy 49 (0):488498.

Zhang, L. and S. X. Zhao 2001. Reinterpretation of China's under-urbanization: a systemic perspective. Habitat International 27:459-483. 